\title{
STUDIES ON RESILIENGE OF HIGH POLYMERS
}

\section{RESILIENCE OF BUTADIENE TYPE SYNTHETIC RUBBERS}

K. Fujimoto (Dunlop Rubber Co. (Japan) Ltd., Laboratory)

In order to study temperature dependence of viscoelasticity, resilience was measured over the temperature range from $-70^{\circ} \mathrm{C}$ to $250^{\circ} \mathrm{C}$. Polybutadiene showed its $\mathrm{Tg}$ at $-70^{\circ} \mathrm{C}$, and it was partially crystallized. 1 st order transition of vulcanizates occured at about $15^{\circ} \mathrm{C}$. Fox's equation could be applied to $\mathrm{Tg}$ of butadiene-styrene copolymers. SBR showed difference of resilience at high temperature region due to difference of polymerization condition. As for resilience near room temperature, cold SBR had superior resilience than hot, and NBR was worst, but resilience of these rubber increased gradually with rising temperature and showed almost constant maximam near $185^{\circ} \mathrm{C}$. The activation energy of glass transition for SBR and NBR was 52.5 and 42.6 $\mathrm{Kcal} / \mathrm{mol}$ erspectively, and these glass transition were corresponded with segment motion having nearly same length as natural rubber.

\section{部分アセチル化ロ紙クロマトグラフ法による 有機加硫促進剤および老化防止剤の分離・確認}

\section{（第了報） 部分アセチル化ロ紙クロマトグラフ法による 加硫コム中の有機加硫促進荗の分離・確認}

(炤和35年9.月29日 受理)

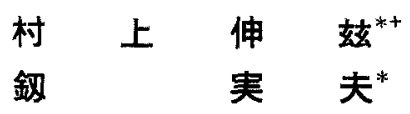

\begin{abstract}
要 旨 純ゴム配合の加硫ゴムのアセトン抽出物加ら来変化の促進剂自身上，促進剂加ら加硫反応中に変化 して出来た生成物を，既に報告した部分アセチル化ロ紙クロマトグラフ法を沈用して検出した。 チアゾール 系の促進剂を用いた時は，DM上 $\mathrm{M}$ の他に MZ を主成分として得だ.チアン゙ール系の中，スルフェンア ミド促進剤はその構成成分てあるアミンも検出した。チウラム系促進剤 TS, TTを使用した時は，TS，TT

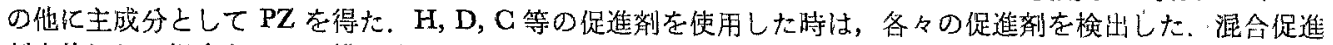
剂を使用した場合も，その構成成分であるもとの促進剂およびそれらからの生成物を検山した，以上の結果 から部分アセチル化口紙クロマトグラフ法は十分実用に供し得ることを認めた。またチアゾール系，チウラ ム系促進剂の場合は促進機構について重要な知見を得るこしが出来た。
\end{abstract}

\section{1. 緒言}

第 1 報”に於て，加硫ゴム中の有機配合剂を分踓・確 畄するためには, 部分アセチル化ロ紙クロマトグラフ法 を応用するのが便利であることを述べた。 また精製した

* 大阪府立大学工学部応用化学科

+ 現職は大津ゴム工業株式念社研究課

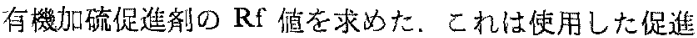
剂を，加硫ゴム中加ら分離・確認するための第一段階七 あった，また第2 報2では，部分了セチル化ロ紙クロマ トグラフ法により，市販湿合促進剂招よび併用されてい る促進威の涯合試料を分济隹・確諗した。

本報では，とれら第1報，第2 報の結棵をもとにして 純ゴム配含の加硫ゴム中の促進剂及び加硫汉灾中そ机ら 
促進剂加ら変化生成した化、令物老，部分了セチル化口紙 クロマトグラフ法により分析し，次の三点在明らがにし $7=$

1. 扣硫促進成は加硫反心中どのような物質に変化す るのか.

2. 打硫時間之加硫促進剂の変化の程度との咸係. これをたしかめるため以下の㥱験を行った。

\section{2. 実験の方法}

\section{1 純ゴム配合加硫ゴムの製作}

配令上

$\begin{array}{lr}\text { 尘ゴム(palc crepe } \# 1) & 100 \\ \text { 画祉荘 } & 5.0 \\ \text { ステアリン睃 } & 1.0 \\ \text { イオウ } & 3.0\end{array}$

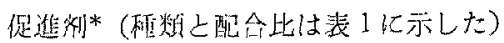

メ防服促進剂をそのまま用いた。

表 1 供試有機吅硫促進剂

\begin{tabular}{|c|c|c|}
\hline \multicolumn{2}{|c|}{$\begin{array}{l}\text { 有機加硫促進利（）内組成 } \\
{[\text { ] }}\end{array}$} & $\begin{array}{l}\text { Pip 会比 } \\
(\mathrm{PHR})\end{array}$ \\
\hline \multicolumn{2}{|c|}{ 2-Mercaptobenzothiazole (M) } & 1.0 \\
\hline \multicolumn{2}{|c|}{ Dibenzothiazolyl disulfide (MD) } & 1.2 \\
\hline \multicolumn{2}{|c|}{$\begin{array}{l}\text { N-Cyclohexyl-2-benzothiazole } \\
\text { sulfenamide }(\mathrm{CZ})\end{array}$} & 1.2 \\
\hline \multicolumn{2}{|c|}{$\begin{array}{l}\text { N-Oxydiethylene-benzothiazole } \\
\text { sullfenamide (MSA) }\end{array}$} & 1.5 \\
\hline \multicolumn{2}{|c|}{$\begin{array}{l}\text { Diethylthiocarbamoyl-2-benzoth iazolyl } \\
\text { s lfide (64) }\end{array}$} & 0.3 \\
\hline \multicolumn{2}{|c|}{ Tetramethyl thiuram monosulficle (TS) } & 0.12 \\
\hline \multicolumn{2}{|c|}{ Tetramethyl thiuram disulfide (TT) } & 0.12 \\
\hline \multicolumn{2}{|c|}{ Hexamethylenetetramine $(\mathbb{H})$} & 2.5 \\
\hline \multicolumn{2}{|c|}{ Diphenylguanidine (D) } & 1.0 \\
\hline \multicolumn{2}{|c|}{ Diphenylthiourea $(\mathrm{C})$} & 3.0 \\
\hline & & 0.12 \\
\hline \multicolumn{3}{|c|}{ " , ๖`ー } \\
\hline$"$ & $\begin{array}{l}\text { ノク Łラ-F[DM(66.5\%) } \\
\quad+\mathrm{H}(24.4 \%)+\mathrm{D}(9.1 \%)]\end{array}$ & 1.2 \\
\hline$" 1$ & $\begin{aligned} \text { サンセラー } \mathrm{A}[\mathrm{TS} / 3 \%) \\
+\mathrm{MZ}(97 \%)]\end{aligned}$ & 1.0 \\
\hline \multicolumn{2}{|c|}{$\begin{aligned} " \quad \text { サンセラー } & 33[\mathrm{TT}(25 \%) \\
+ & +\mathrm{MZ}(75 \%)]\end{aligned}$} & 1.0 \\
\hline \multicolumn{2}{|c|}{ M+D の作网 } & 10.4 D 0.6 \\
\hline \multicolumn{2}{|c|}{$\mathrm{D}+\mathrm{TT}$ の伤的 } & 1.0 TT 0.2 \\
\hline
\end{tabular}

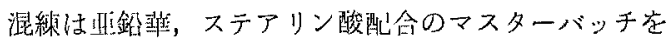
怍り，その一部老とりイオウと各種促拈剂を配合した。 泟練のち法は，大体 ASTM D15-52T（ゴム工業便覽， 744面）に蕉拠した。
加硫条件 加硫温度 : $147 \pm 1^{\circ} \mathrm{C}$

air press $: 6.5 \mathrm{~kg} / \mathrm{cm}^{2}$

加硫時閏：3，5，10，15，20,25min

\section{2 加硫ゴ么試料の物理試験}

扣硫ゴ么試料の加硫状態〔加硫不足，最適加硫，加硫 過度了をみるため，下記の物理試験を行った。

1. 硕さ (JIS)

2. $500 \%$ モジェラス $\left(\mathrm{kg} / \mathrm{cm}^{2}\right)$

3. 湖び (\%)

4. 汀张陷さ $\left(\mathrm{kg} / \mathrm{cm}^{2}\right)$

\section{3 薬 剂}

ロ紙のアセチル化に朋いた渻剂と展開溶媒として用い た落剂の精製法は第 1 報と同じ，加硫ゴム試料のアセ卜 ン抽仙には，試留 1 級品を無水炭酸ソーダと其に蒸溜, 精製したアセトンを用いた。

\section{4 口紙}

東洋口紙 No.51 (6×40cm) 在部分ア七チル化して用 いた，紙をアセチル化する方法及びアセチル化口維の アセチル化度分析法は第 1 報に述べた通りである。

\section{5 加硫ゴム試料からクロマトグラフ法にかける試料} 溶夜の調製

加硫ゴム試料 $8 \mathrm{~g}$ 岂出来るだけこまかく切り，ソック スレー抽出装置で8〜10hrアセトン抽出する，ての際， 批兌れた促進剂等が分解しないよう浴温は $80^{\circ} \mathrm{C}$ をこ えないようにするる゙. 抽出後出来るだけ低温でアセトン 在追出し，抵出物を約 $2 \mathrm{ml}$ のベンゼンに溶解する。 た だし促進郕 D, H 括よび C を用いた加硫ゴムからの抽㑁 物はメタノ一ルに溶解する。 また促進剂 CZ, MSA, 混 合促進剂ノクセラー MIX No. $3(\mathrm{DM}+\mathrm{H})$ ，ノクセラー $\mathrm{F}(\mathrm{DM}+\mathrm{H}+\mathrm{D})$ を用いた加硫ゴム及び， $\mathrm{M}+\mathrm{D}, \mathrm{D}+\mathrm{TT}$ の併用をした加硫ゴムからの抽出物はメタノール, ベン ゼンの二通りの溶液を作る。なおとれらのベンゼン溶液 或いはメタノール溶液は，沈でんしているイオウを除く たか一度口過してからロ紙てスポットする。

\section{6 標準試料}

加硫ゴム試料から抽们した促進剂および加硫反応中こ れら促進剤から変化して坐成した物質を, 部分アセチル 化ロ紙クロフトグラフ法で分離・確認する場合，てれら

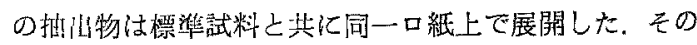
標準試料溶液の浴媒と浱度を表 2 亿示した．標準試料と は使用した促進戍が未变化で残っている場合は精製した 促進郕そのものを用い，また变化すると考えられる場合 は生成する牙が予想される化合物を用い，それらが存在 するから゙うか存確諰（同定）するために用いた。 
表 2 楢 蕉試 料

\begin{tabular}{|c|c|}
\hline 㯲準試料（）内は略名 & 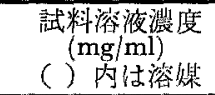 \\
\hline Mercaptobeznothiazole (M) & $20($ メタノール) \\
\hline Dibenzothizolyl disulfide (DM) & 10 (ベンゼン) \\
\hline $\begin{array}{l}\text { Zinc salt of 2-mercaptobenzothiazole } \\
(\mathrm{MZ})\end{array}$ & 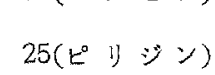 \\
\hline $\begin{array}{l}\text { N-Cyclohexyl-2-benzoiathzole } \\
\text { sulfenamide (CZ) }\end{array}$ & $20($ メタノール) \\
\hline $\begin{array}{r}\text { N-Oxydiethylene-2-b } \\
\text { sulf }\end{array}$ & $20($ メタノール) \\
\hline Cyclohexylamine* & \\
\hline e $(64)$ & 20(ベンゼン) \\
\hline etramethyl thiuram monosulfide(TS) & 25(ベンゼン) \\
\hline$(\mathrm{TT})$ & 25(ベンゼン) \\
\hline TET) & 25(ベンゼン) \\
\hline$(\mathrm{PZ})$ & $20\left(ヒ^{\circ}\right.$ リジン) \\
\hline e $(E Z)$ & $50\left(ヒ^{\circ}\right.$ リジン) \\
\hline Hexame & 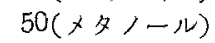 \\
\hline Dipheny & $100($ ×タ $1 ー ル)$ \\
\hline Diphenylthiourea (C) & 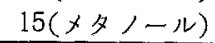 \\
\hline \multicolumn{2}{|c|}{ 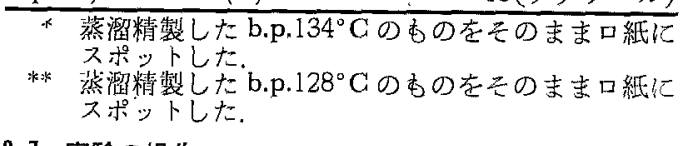 } \\
\hline
\end{tabular}

\section{7 実験の操作}

展開操作 口紙の端加ら $6 \mathrm{~cm}$ の位置に原線を，原線
加ら $20 \mathrm{~cm}$ の位蹎に終線を引き，原線の上に拙出試料と

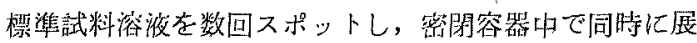
開を行った。

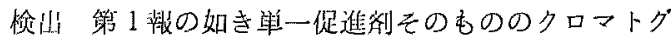

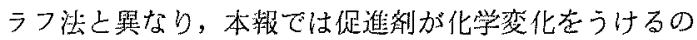
で各試料につき㭘出法は買なりまた復熦よなる。3.1で 各武料について述べる。

\section{3. 実験結果及び考察}

\section{1 純ゴム配合加硫ゴムのアセトン抽出物の部分アセ チル化ロ紙クロマトグラム}

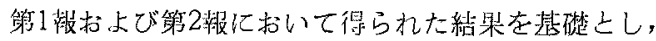
部分アセチル化ロ紙クロマトグラフ法老行った際の儌 閶条件〔使用した口紙のア七チル化度および展開浴媒】 よスポットの検出法求よび得られたクロマトグラムを各 々の加硫ゴム拙出陚料について示す，但し加䖻ゴム試料

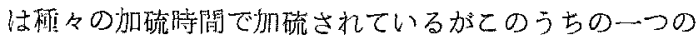
試料汇ついて, 致開条件, スポットの検出法, クロマト グラムを示す，配合を同じくし加硫時間のみを異にする 他の拙出試料からのクロマトグラムは全く同じであるの で省略した、ただ、スポットの大きさが外観上異なるの みである。このスポットの大きさから，定性的ではある が使用した促進剂上をれから変化生成した化合物の量在 推定し得る。この結果については後に3.2 で过心゙る。

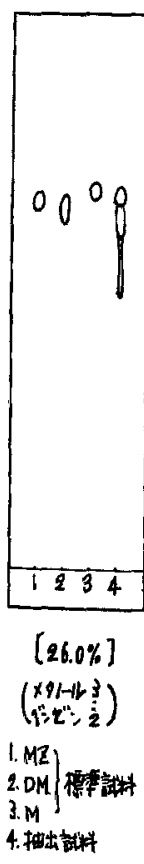

南 1

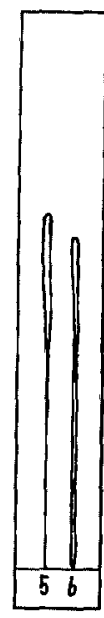

[26.0\%]

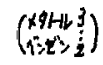

5. MZ 程转辚 6. 程出新栍

怄 2

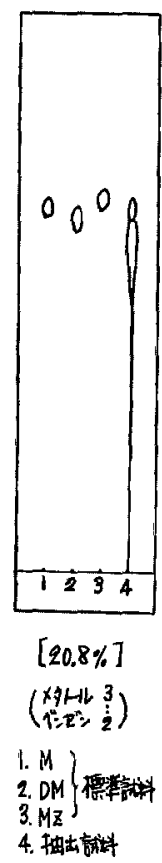

淄 3

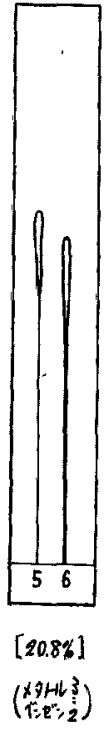

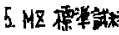
6. 抽坛誠柈

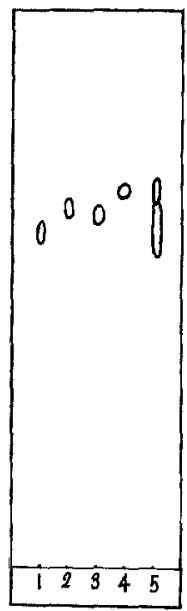

[20.8\%]

$\left(\begin{array}{cc}x & 41-1 \\ 1 ゙ \div ヒ ゙ \% & 3 \\ 2\end{array}\right)$

I. $M Z$

2. $M$ 3. $D M$

$4 C Z$

5. 㡒出誡料

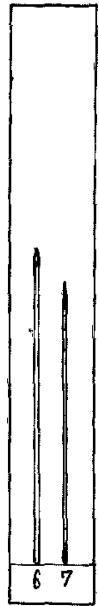

$(49+1) ? 3$

6. MZ

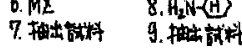

図 4
[20.8\%]

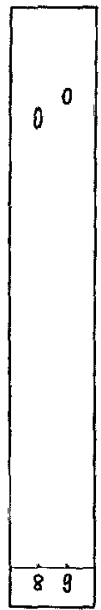

[20\%]

$\left(\begin{array}{l}\times 91+1,3 \\ 1: * t ; \\ 2\end{array}\right)$

$\mathrm{H}_{2} \mathrm{~N}$ (-1)

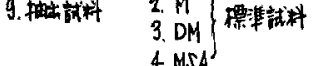

5. 㯰出試料

约 7 的 8

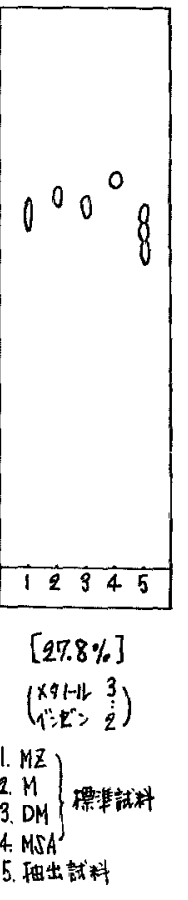

|⿰氵⿶凵| 6 

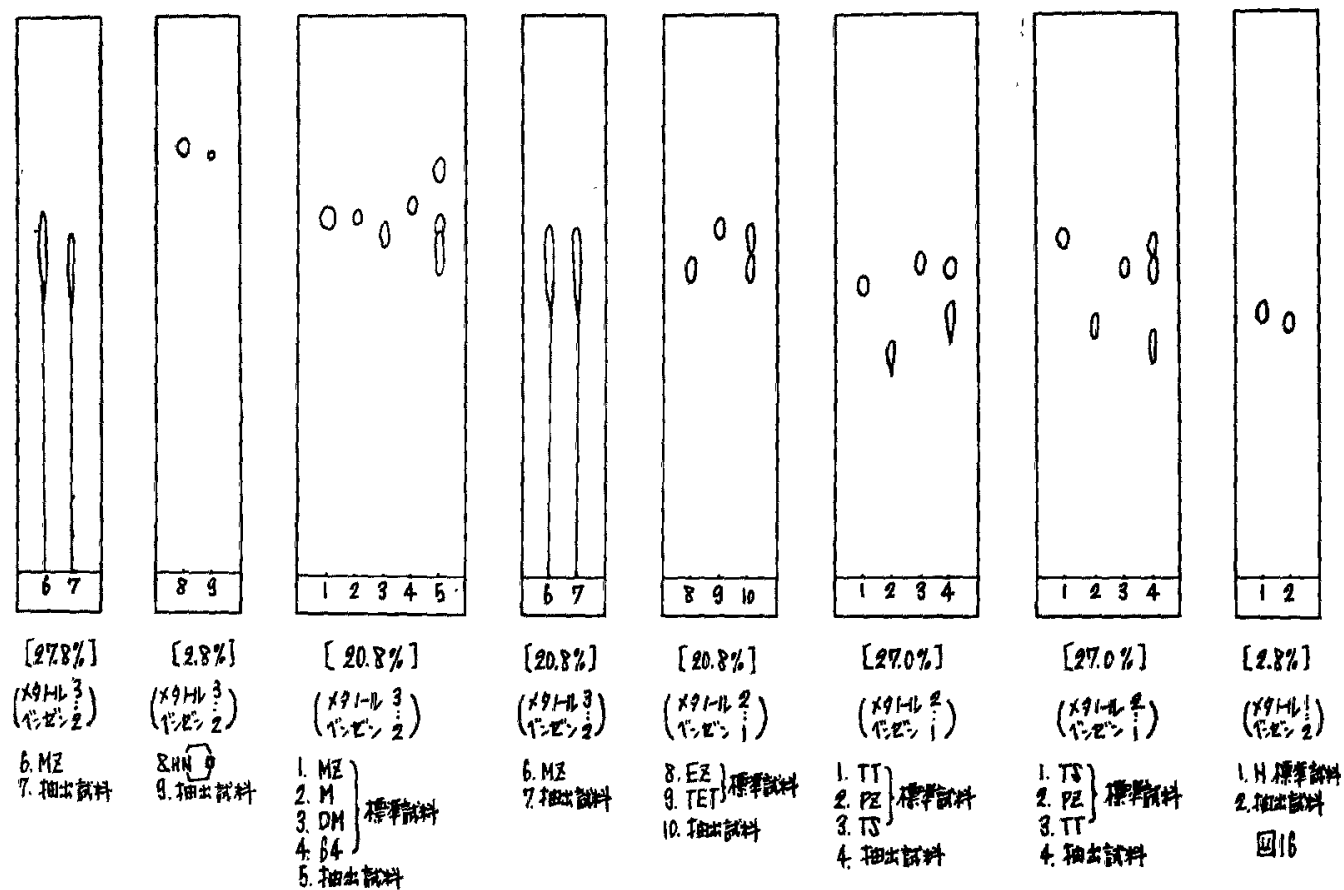

涩 910

圈11

国 12

比13

国 14

図 15

闵 16
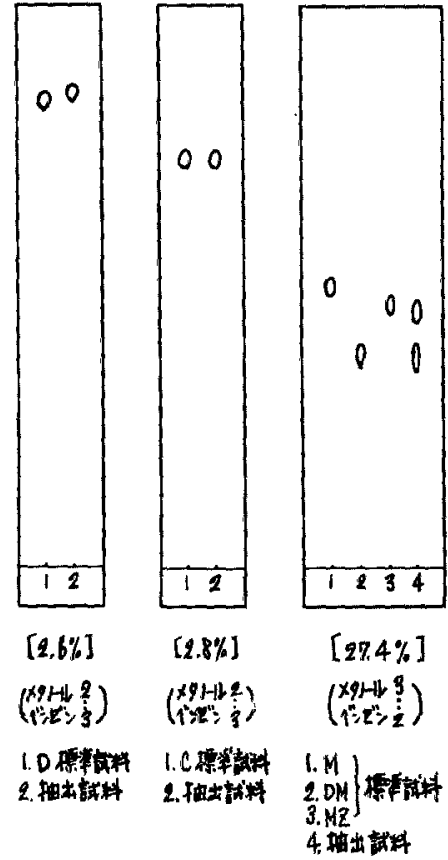

$[17$

脳 18

図 19

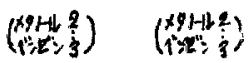
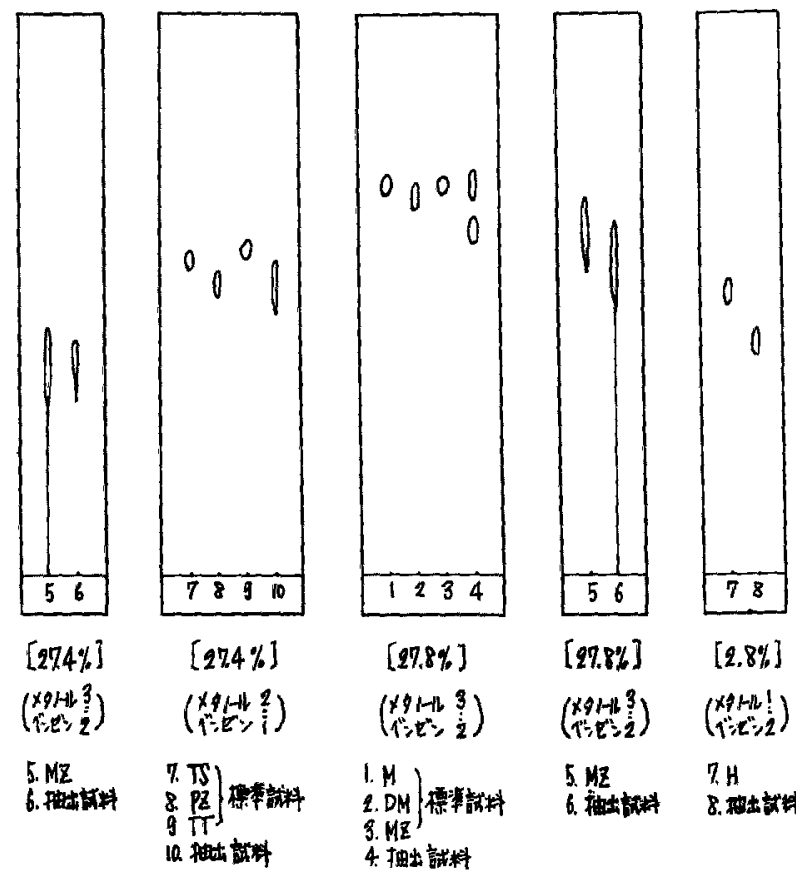

$\left(\begin{array}{l}x, 1+1,3 \\ f, e^{*} \geq 2\end{array}\right)$

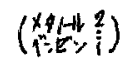

$\left(\begin{array}{l}x y+-1 b \\ n^{2}=t^{3}=2\end{array}\right)$

$\left(\begin{array}{c}x+1+n ! \\ 1 " x x^{\prime}=2\end{array}\right)$

5. $M(2)$

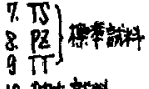

5. $\mathrm{NZ}$

7. H

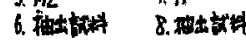

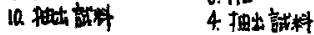

図20

図21

政2

図23

図24 


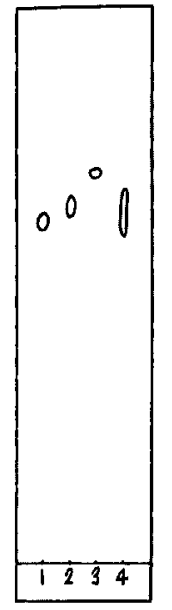

[27.8\%]

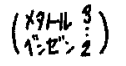

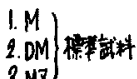

3.MZ

4. 柚出就枓

図25

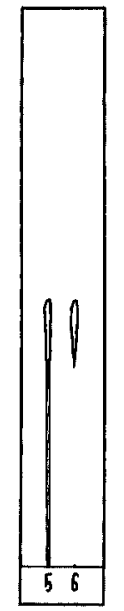

[27.8\%]

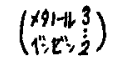

5. MZ

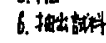

כo

図2s

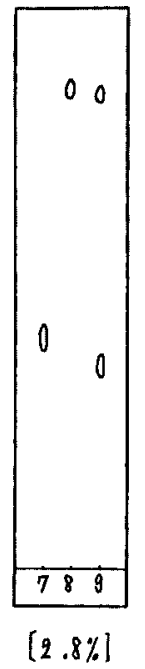

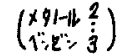

7. $\mathrm{H}$

8.D

9. 挴蛙料

[ख्र|27

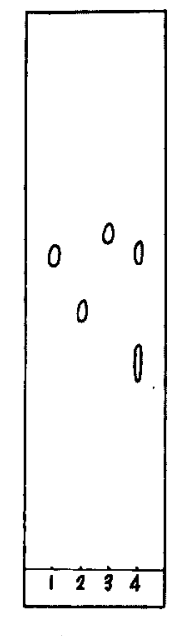

[19.7\%.]

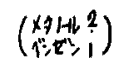

I. $T$ )

2. $P Z\}$ 标毃计

4. 抽坛就科

四28

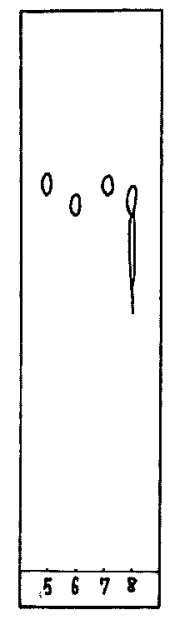

[19.7\%]

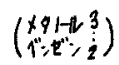

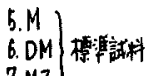

7. MZ

8. 抽出誡㭌

㘣 29

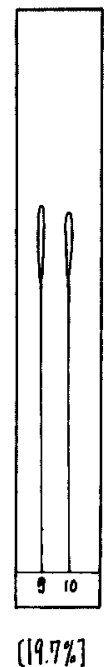

$(x+1-1 k ? 3)$

$9.4 z$

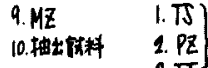

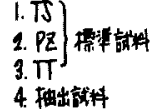

清31

図30

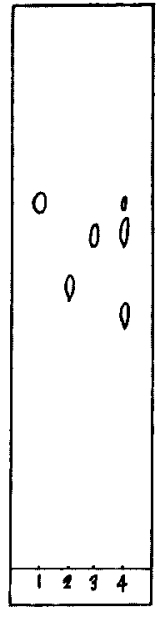

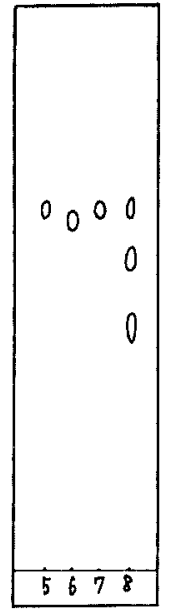

[22.8\%]

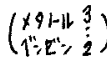

5.M )

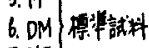

7. $M Z$

8. 抽出謨料

这32

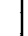

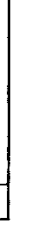
)
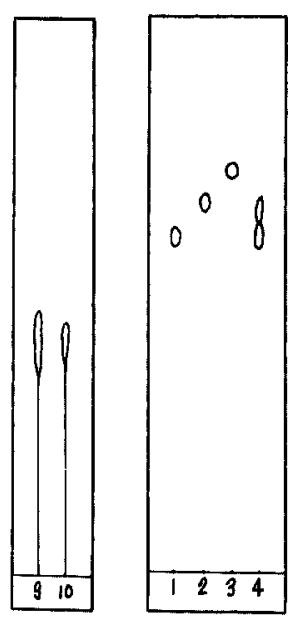

[29.8\%]

$\left(\begin{array}{l}18+11 \\ 14: t^{\prime \prime}, 2 \\ \dot{2}\end{array}\right)$

9. MZ

10.抽出赫料

図33

( 47 )
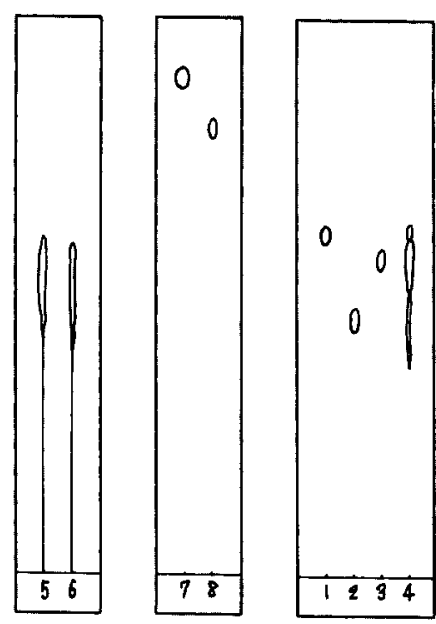

00 
3.1.12-Mercaptohenzothiazole（M) を用いた純 ゴム配合加硫ゴム試料 〔〕は使朋した口紙のアセチル 化度，以下同じ（）注開溶暩，以下同じ，4及び 6 の抽山誈料优加硫時間 $10 \mathrm{~min} も の も 。$

スポットの検出方法：図１は展開安終えた口紙を白金

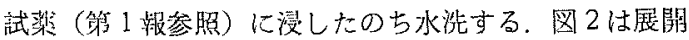

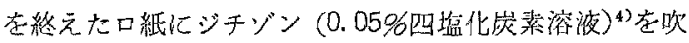
きつける。（図10方法では DM 上 MZ のスポットが

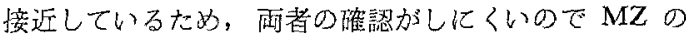
みを発色するジチゾンを朋いて，更に図 2 の方法で展開 し MZ を確認した， MZ はジチゾンにより赤紧兒に星 仙する。)

3.1.2 Dibenzothiazoly1 disulfide (DM) を用いた 純ゴム配合加硫ゴム試料 4 および6の拍仙試料は加硫 時問 $25 \mathrm{~min}$ のもの.

スポットの検出方法は $M$ の場合と全く同じ。

3. 1. 3 N-Cyclohexyl-2-benzothiazole sulfenamide （CZ）を用いた純ゴム配合加硫ゴム試料 5，7及び90

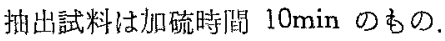

スポットの検出方法：図５住開老終えた口紙を白金 試薬に浸したのち水洮する。図6は展開を終えた口紙に ジチゾンを吹きつける。図 7 は展開定終えた口紙に $\mathrm{pH}$ 指示藻ブロムフェノールブルー（ベンゼン溶液）を吹き つける。

3.1. 4 N-Oxydiethylene-benzothiazole sulfenamide (MSA) を用いた純ゴム配合加硫ゴム試料 5，7 及び9の抽讪試料は加硫時問 5 minのむの.

スポットの検出方法は CZ の場合之全く同じ，

3. 1.5 Diethylthiocarbamoyl-2-benzothiazolylsulfide(64)を用いた純ゴム配合加硫ゴム試料 5，7括よ

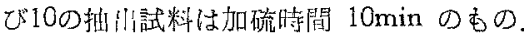

スポットの検出方法：図11惃開崖終えた口紙を白金

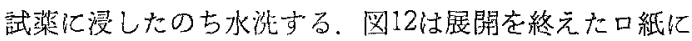
ジチゾンを吹きつける，図13は展開を終えた口紙を硫酸 銅水腹液 $\left(90^{\circ} \mathrm{C}\right)$ に没したのち水湤し，白金試薬に浸し てから水洗する。

3.1.6 Tetramethyl thiuram monosulfide (TS) を用いた純ゴム配合加硫ゴム試料４00拍出試料は扣硫 㭙問 $15 \mathrm{~min}$ のもの.

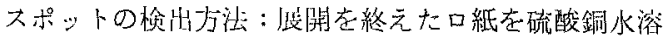
液 $\left(90^{\circ} \mathrm{C}\right.$ 位) に浸したのち水沉し，白金試楽に浸して水 沙する。

3.1.7 Tetramethyl thiuram disulfide (TT) を用 いた純ゴム配合加硫ゴム試料４の抽出試料は加硫時临
$20 \min の も の$.

スホットの検山方法はTSの場合と全く同じ.

3.1.8 Hexamethylenetetramine $(\boldsymbol{H})$ を用いた純 ゴム配合加硫ゴム試料 2 の抽出試料は加硫時間 $10 \mathrm{~min}$ の毛の.

スポットの検山方法：琵開を終えた口紙に $\mathrm{pH}$ 指示䉾

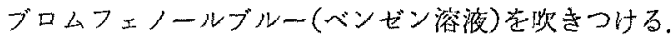

3.1.9 Diphenylguanidine $(D)$ を用いた純ゴム配 合加硫ゴム試料 2 の捪证試料は打硫時间 $20 \mathrm{~min} の$ 委 D.

スポットの榆出方法は $\mathrm{H}$ の啰合と全く同じ。

3.1.10 Diphenylthiourea (C) を用いた純ゴム配合 加硫ゴム試料 2 の抽出試料は加硫時問 $25 \mathrm{~min}$ のの.

スポットの检出方法：展開在終えた口紙を白金試渻に 浸す。

3.1 .11 混合促進剂ノクセラー21（TT+M) 用いた 純ゴム配合加硫ゴム試料 $4 ， 6$ および100抽出試料は 㧈硫時間 $10 \mathrm{~min}$ の屯の.

スポットの㭘出方法：図19は度開を終えた口紙を白金 試桬に浸したのち水沈する。图20は展開を終えた口紙に ジチゾンを吹きつける，図21は展開を終えた口䋏を硫酸 銅水溶液 $\left(90^{\circ} \mathrm{C}\right)$ に浸したのち, 水沙してから白金試浆 に漫し水㴶する

3. 1.12 混合促進剂ノクセラー mix No.3 $(\mathbf{D M}+\mathbf{H})$ を用いた純ゴム配合加硫試料 $4 ， 6$ および8の抽出試 料は加硫時間 $10 \mathrm{~min}$ のあの.

スポットの愉牥方法・図22は屡開を終えた口紙を白金 試楽に浸したのち水沙する。図23は展開を終えた口䋏に ジチゾンを吹きつける，図24は履開を終えた口紙に $\mathrm{pH}$ 指示殞ブロムフェノールブルーを吹きつる。

3. 1.13 混合促進剤ノクセラーF (DM+H+D) を用 いた純ゴム配合加硫ゴム試料 $4 ， 6$ および9の抽出試 料は加硫洔間 $5 \mathrm{~min} の$ の。.

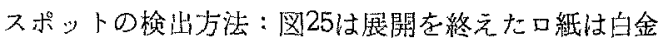
試薬に浸してから水洗する，図26は展開を終えた口紙に ジチゾンを吹きつける，図27は展開を終えた口紙に pH 指示薬ブロムフェノールブルーを吹きつける。

3.1.14 混合促進剤サンセラーA(TS $+\mathbf{M Z})$ を用いた 純ゴム配合加硫ゴム試料 4,8 打よび10の抽治試料はか 硫時閶 $10 \mathrm{~min}$ のむの.

スポットの検出方法：図28は展開を終えた口紙を硫蝬 銅水溶液 $\left(90^{\circ} \mathrm{C}\right)$ に浸し水洉して加ら，白金試薬に浸し て水洗する。図29は展開を總えた口紙を白金試㭗に浸し てから水洗する、図30は展開を終えた口紙にジチゾンを 
吹きつ汁石。

3.1.15 混合促進剂サンセラー $33(T T+M Z)$ を用い た純ゴム配合加硫ゴム試料 4,8 不び100抽仙試料は加 硫時關 $3 \mathrm{~min} の 60$.

スポットの检出方法はサンセラー A の㗪合と全く同 じ.

3.1 .16 促進剂 $\mathbf{M} と \mathbf{D}$ の併用をした純ゴム配合加硫

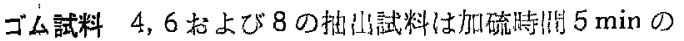
屯D.

スポットの検出方法：図34は展開を終えた口紙を白全

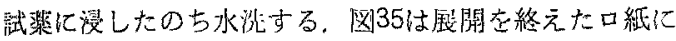
ジチゾンを吹きつける。图36は展開を終えた口紙に pH 指示咀ブロムフェノールブルーを炏きつける。
3.1 .17 促進剂 $\mathbf{D}\llcorner\mathbf{T T}$ を併用した純ゴム配合加硫 ゴム試料 4 および 6 の抽出試料は加硫時䦕 5 min のも $\infty$.

スポットの检出方法：図37は墕開定終えた口紙を硫酸 䞒水溶液 $\left(90^{\circ} \mathrm{C}\right)$ に浸し水沙してから，白金試楽に浸し て水㳘する．図38は展開を終えた口紙に pH 指示蒋ブロ ムフーノールブルーを吹きつける。

\section{2 部分アセチル化ロ紙クロマトグラフ法による純ゴ} 么配合加硫ゴムの分析結果

3.1のクロマトグラムの位置执よび発色したスポット

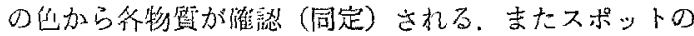

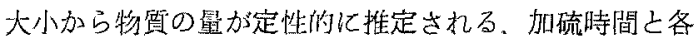

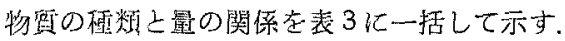

表 3 加硫ゴム中から検任された促進剂书よび加硫仅応変化生成物

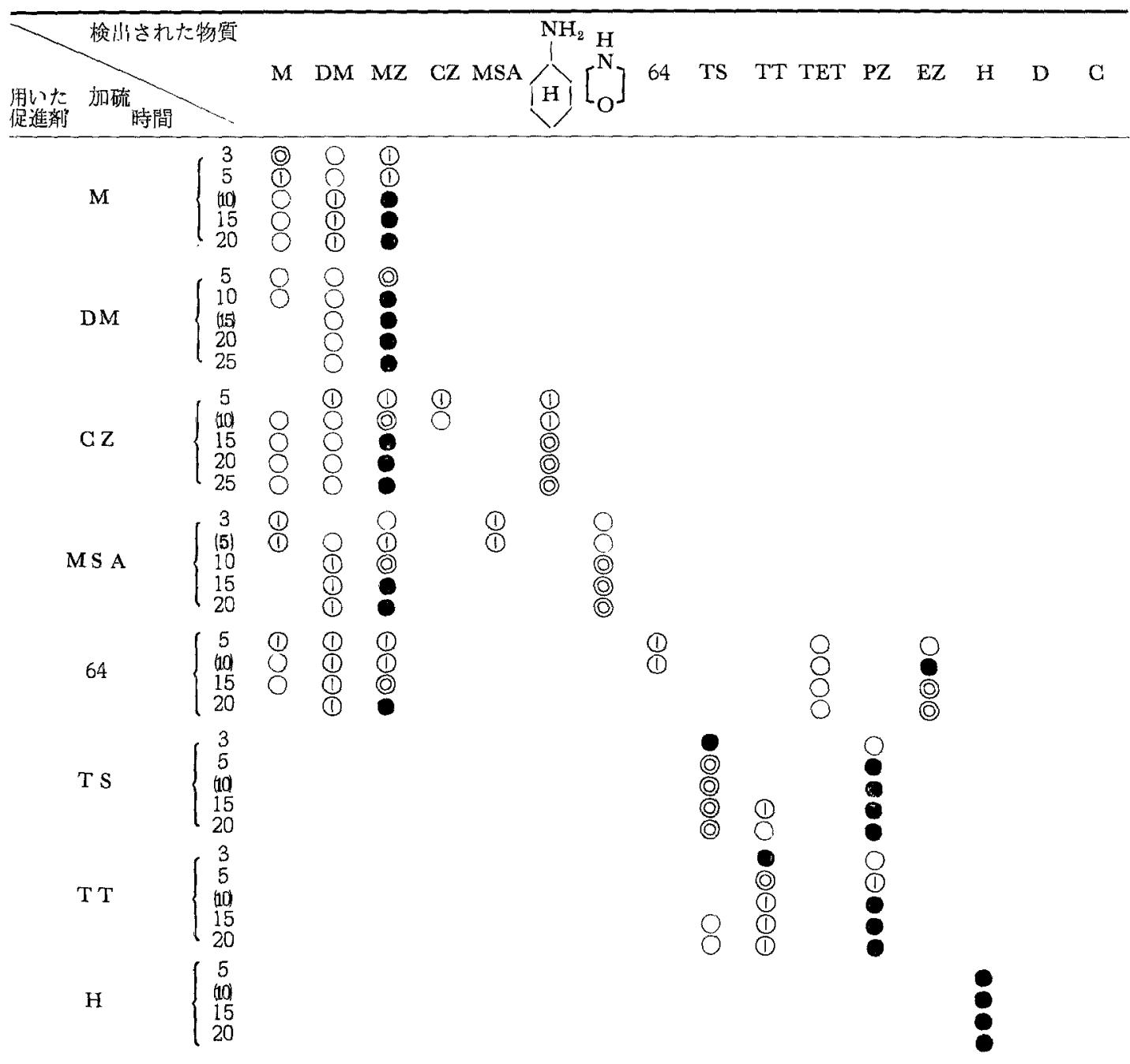




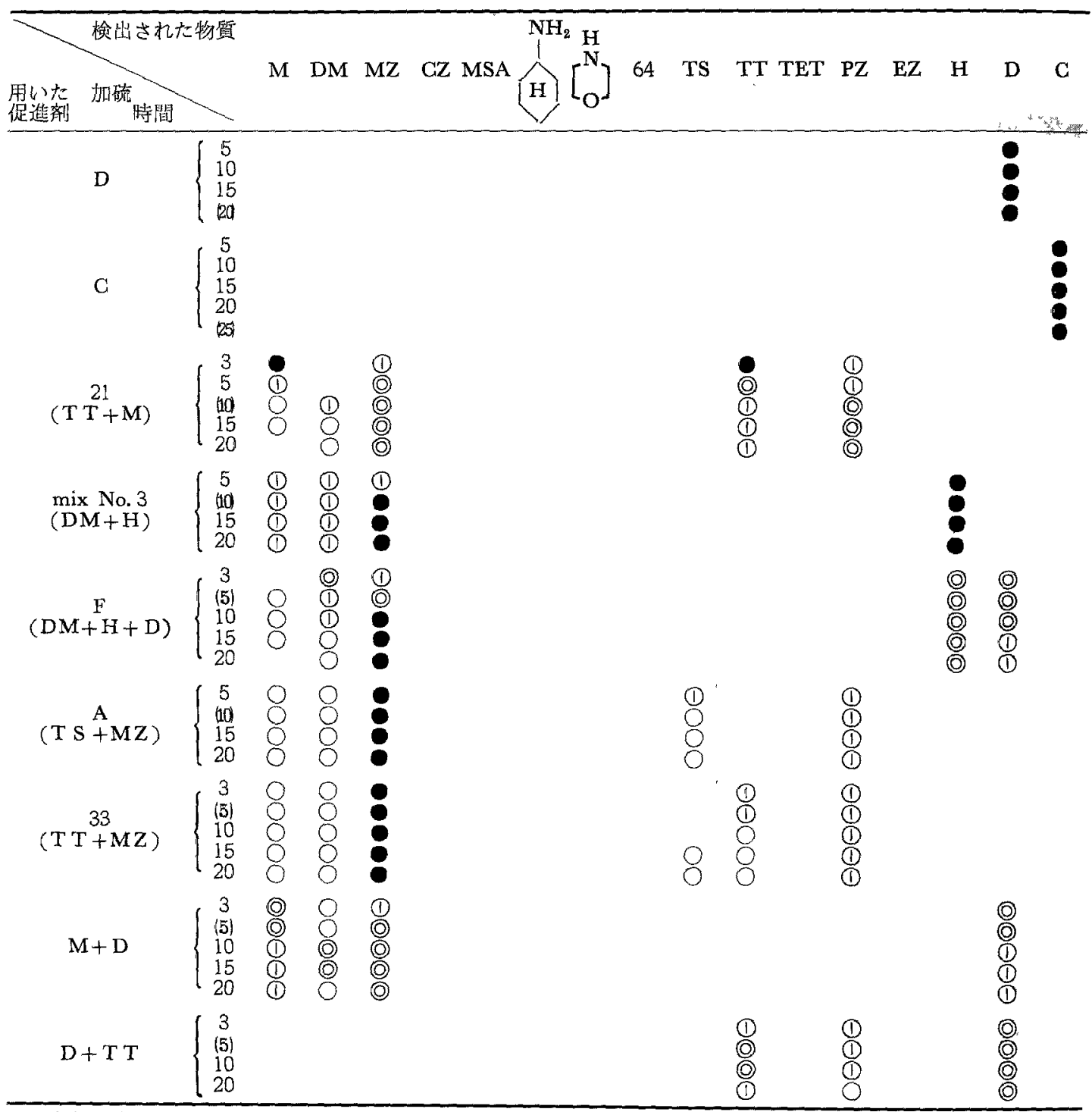

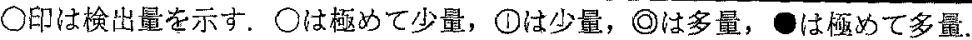

（）印は2.2加硫ゴんの物理試験から求めた最適加硫㭙問を示す。

\section{3 部分アセチル化口紙クロマトグラフ法による加硫} ゴム中の促進剤の分析結果に対する考察

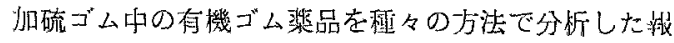
告は数多くあるが，口紙クロマトグラフ法に上って系統 だてて，加硫ゴム中の促進剂及び扣硫反応中それらから 変化して坐成した化合物を分離・淮認した例はなく，又 加硫促進削の変化の程度亡加硫時間との関係索明ら加飞 した報告もない，著偖らが確認し得た表 3 の結果の促進 剂加ら变化生成した化合物は，乙れ迄住報告されている
灵験結果とよく一致している．参劣迄に二・三の外国の 银告と比烄してみると, M.J. Brock and George D.

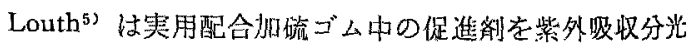
分析法しX線回折法で伃析して次の上うな結果を出して いる．Ｍ在用いた加硫ゴム中からは $\mathrm{M}$ を，DMを用い た加硫ゴム中加らは $\mathrm{M}$ を， $\mathrm{CZ}$ を用いた加硫ゴム中加 らは M とシクロヘキシルアミンを，MSA を用いた楖 硫ゴム中からは M とモルフォリンを，64を朋いた加硫 ゴム中からは $\mathrm{M}$ 之分解生成物としてジェチルアミンを， 
TS または TT を用いた加硫ゴム中加らは抑山物を酸性: で処理したときの分解生成物としてジメチルアミンを， Dを用いた加硫ゴム中からは D妾それぞれ尔離・確認 している、また C.A. Parker ${ }^{6}$ 洁シリカゲルカラムクロ マトグラフ法で加硫ゴムアセトン抽出物を分離後, 紫外 吸收分光分析に加けて次のような結果老出してい吕， $\mathbf{M}$ を用いた加硫ゴ么中からは M, DMを，DM存用いた 加硫ゴム中からは $\mathrm{M} ， \mathrm{DM}$ を，CZを䀦いた加硫ゴム中 からはM，DM，CZを，TSまたはTTを用いた加硫ゴ ム中からは PZを，Dを用いた加硫ゴム中からは Dを， Cを朋いた加硫ゴム中加らは $\mathrm{C}$ 走それぞれ分嵟・確㒛 している。

本報の図 1 から図38迄のクロマトグラムをみるよ、一 般に抽出試料から得たクロマトグラムの Rf 值は檪準試 料の Rf 值より幾分小さい，乙れは抽仙試料が促進剂お

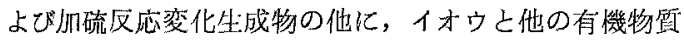
を含むためであろう。しかし大部分のイオウは $\mathbf{R f}=0$ となって分離される。このことはイオウを部分アセチル 化口紙クロマトグラフ法に加けて硫か力た。イオウと一 種類の促進剂の混合試料のメ夕ノールを溶煤とした溶液 では，イオウは $\mathrm{Rf}=0$ として分離されるが，ベンゼン を溶媒टした試料溶液ではイオウの溶解している量が多 く、イオウ自身は $\mathrm{Rf}=0$ として分離・確認さ机るが， 他の成分の Rf 值を幾分低下せしぬる様仁作用するのて あ万う。抽出物質の確認は発色したスポットの色からあ 十分行える

如何なる促進剂存用いたか未知の加碳ゴムについて促 進剂を確認することは，この部分アセチル化口維クロマ トグラフ法を处用すれば十分可能であるが，その加硫ゴ ムが加硫過度の試料である場合に，MとDM のいずれ の促進剂を用いたか，またTSとTTのいずれの促進剂 存用いたかを決めるこ上は困離であ万う.と扎は後に3.4

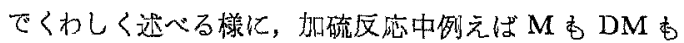
いずれも $\mathrm{MZ}$ になり，加硫時䦎の覧いむのでは最初に 用いた促進牛が $\mathrm{M}$ か DM であったかの判定にすずかし くなるであるう。これは加硫促進剂の促進作用の本質的 な問題であり，分析法の問題で奴ないししし加硫時間が 最適加硫時閻以前であると，M D DM の区别於よびTS 上TTの区别は可能であると将えら机る。また CZ, MSA は各々の構成アミンを检出する到により，明らかに他の チアゾール系促進剂上区別しうる，H，D，C はそれらが 加硫反応後も残っている埸合，明らかに識別出来る，混 合促進剂の場合はそれぞれの成分が識別出来る・ただし， Mまたは DM，TSまたはTT が混合促進剂の一成分と
して用いられた時は上に述べた混乱が起る呇はさけら扎 ない.

以上の絬果をむとにして，今後は米知の加硫ゴム試料 から促進戍を識別し得るか否かを試みたいと考えてい る、続報は老化防止剂の部分アセチル化口紙クロマトグ ラフ法について報告するが，老化防止剂を加硫ゴム中か ら識别することに成功した後は，末知の加硫ゴムから促 進剂，老化防止剂の一齐分析隹みたい。

\section{4 加硫ゴム中の加硫促進刘の 分析結果より加硫促進 機構の考察}

3.4.1 チアソール系促進剂について $\mathrm{M}, \mathrm{DM}, \mathrm{CZ}$, MSA の様にチアゾール基をむつ促進剂はいずれも加硫 反応中 $\mathrm{MZ}$ となる殅が認められた， $\mathrm{M}$ ，DM の場合， 扣硫中に MZになる事は既化他の研究者により確められ ているマる゙ また著者の一人はジフェニルメタンをゴム のモデルとした時， $\mathrm{M} ， \mathrm{DM}$ は次の如く挙動することを 確めてい合㝵10)。

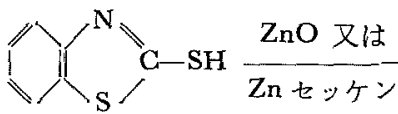

(M)

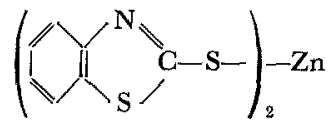

(MZ)

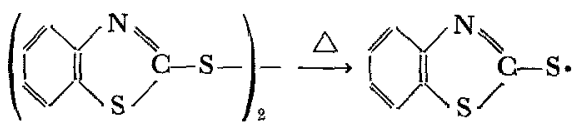

(DM)

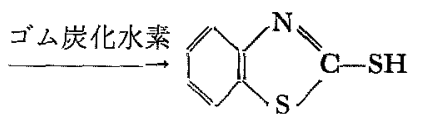

(M)

$\mathrm{DM}$ より(2)索へて生じた $\mathrm{M}$ は (1) の如く反店して $\mathrm{MZ}$ しなる，ここで生じた $\mathrm{MZ}$ は $\mathrm{S}_{8}$ 器状分子と反応して次 の如〈なる 万早10)。

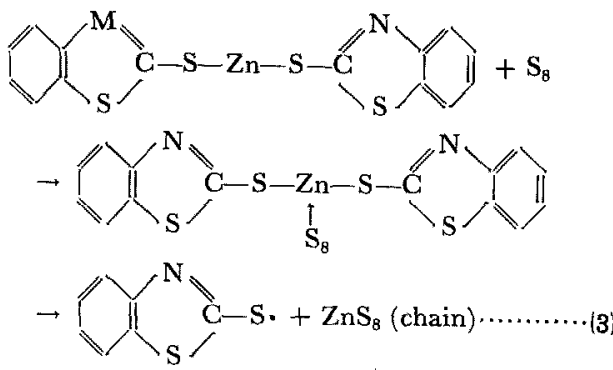

(3)で生じたベンゾチアゾールスルフェールラジカルは(2) 
により $\mathrm{M}$ となり，再び(1)により $\mathrm{MZ}$ よなって循環して いる.

CZ, MSA Kついてはスルフェンアミド系促進刹につ いて言われている如く， S-N 結合の開裂により反応は 始ま百11

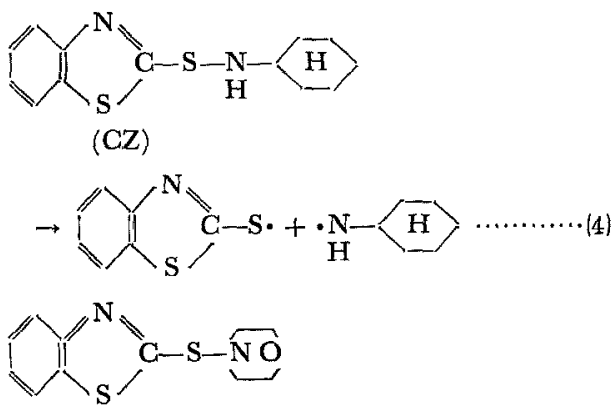

(MSA)<smiles></smiles>

(4)，(5)で生じたアミンラジカルはゴムを脱水装させてア ミン上なる。ベンゾチアゾールスルフェールラジカルは 既に述べた漛に，(2)，(1)，(3)の過程を循環する。

チアゾール系促進剂 M，DM，CZ，MSAからはず れ香多量の MZ（こ机泇硫反応時閒之共化生成量が增 加）及び多量のMを先ずる理由は上の如く説明される。た だし，本報ではMをはじめとしてすべてのチアソール系 促進剂からは少量の DM 怔発生している。 ジフェニル メタンを用いたモデル実験では，少くとす $\mathrm{M}$ を使用し た時は DM は生成されなかった。との差はジフェニル メタンのような低分子物質をモデルとする事に原因し， 恐らくゴムの如き高分子量の高粘度の物質中では拡散の 速度が扔そいため，次のような dimerization（二量化） が起きるのであるう。

2<smiles></smiles>

との点については今後詳細な研觉を必要とする，

3.4.2 チウラム系促進剂 TS, TT のうち TT は問 題なく $\mathrm{S}-\mathrm{S}$ 結合の fission (開裂) から反応が始まる。

$$
\begin{aligned}
& \left(\underset{\mathrm{S}}{\mathrm{Me}_{2} \mathrm{NC}-\mathrm{S}-}\right)_{2} \rightarrow \mathrm{Me}_{\mathrm{S}} \mathrm{NG}_{\|} \mathrm{S} . \\
& \underset{\mathrm{S}}{\stackrel{\text { ゴム炭化水媇 }}{\rightarrow}} \mathrm{Me}_{2} \mathrm{NC}-\mathrm{SH}
\end{aligned}
$$

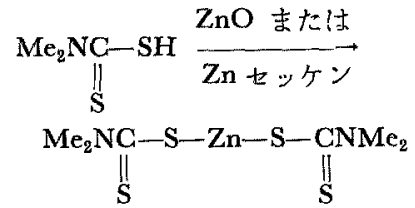

(PZ)

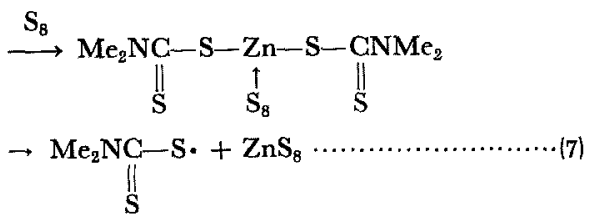

TTより TS の生成は次の如く解釈される。<smiles>CN(C)C(=S)SC(C)(C)C</smiles>

(TT)

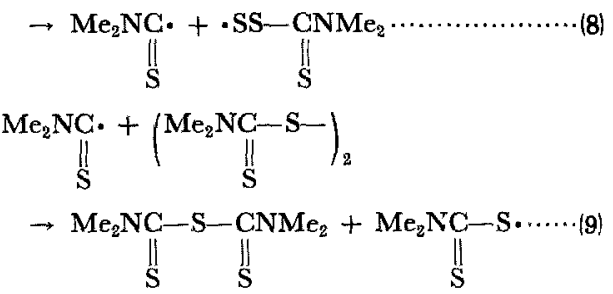

(TS)

TSより TT の生成は

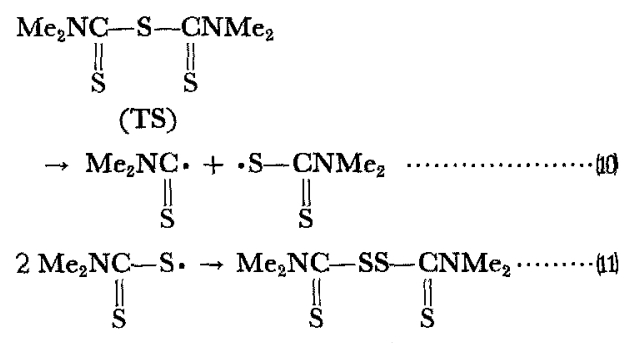

(TT)

(10)式で生じた $\mathrm{Me}_{2} \mathrm{NC}$. (thiocarbamyl ラジカル) は(9) II

式の反応を，(9), (10式で生じた $\mathrm{Me}_{2} \mathrm{NC}$-S.ラジカルは $\stackrel{\mathbf{S}}{\mathbf{S}}$

(6)式で dithiocarbamic acid となり，これは式で $\mathrm{PZ}$ となりついですとのラジカルとなる。この様に循環し ている．以上の如く，TS，TTより PZの生成（とれは 反応㭙間亡共に多〈なる）が説明される．著者の 1 人は ジフェニルメタン在モデルとしてチウラム系促進郕の促 速機構定研究しているが(2)，この際にも上述と同じメカ ニズムを推論している.

\subsection{3 促進剂64について}




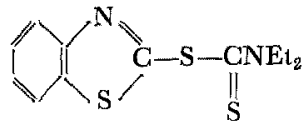

(64)

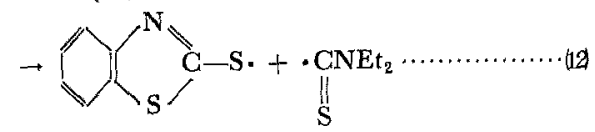

の如〈切机た場合，ベンゾチアゾールスルフェニルラジ カルから M, DM, MZ を生成することは，3.4.1 の反 応機槵の通り説明される。また

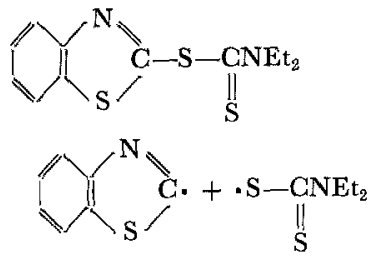

の如く切れた場合， $\mathrm{Et}_{2} \mathrm{NC}-\mathrm{S}$. 加ら EZ，TET の生成 S

は3.4.2で行った説明の類推から容易比説明出来る・ただ

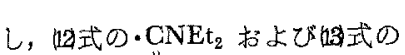
S<smiles>O=C1CNC2=C(C=CCC2)S1</smiles>

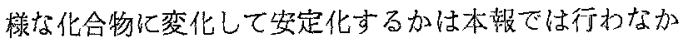
った，TTを加硫剂として用いた場合およよ゙促進郕とし て用いた場合，TT から如何なる化合物が得られるかは short path distillation により確められている( ${ }^{132}$. 本報で 毛TTから生成すると予想されるあら枕る化合物を別に 合成し，それを標準試料として加疏ゴム抽出物と比烄す れば，そ机らの生成が確認さ机るわけである。との事は チアゾール系, チウラム系等一般の促進䨩についてもあ てはまる。しかし本瓣の目的は，いかなる促進剂を加硫 に際して使用した加を梌出するのに古ったから上述のこ 亡は行わなかった。.今後の研究の対象之したい．

3.4.4 その他の促進剂 $\mathrm{H}, \mathrm{D}$ ，C等の促進剂はこれ を用いた加硫ゴム中から，加硫反応後む残存している冬
々の促進剂自身を検山したに過ざない。と礼らの促進剂 の促進機謿は勿論本部の籍围外にある。

\section{4. 総括}

扣硫ゴムからのアセトン抽仙物を部分アセチル化口紙 クロマトグラフ法により分析して次の結諭を得た。

1) 使用した促進剂また经促進剂加変化した生成物

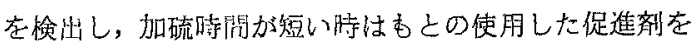
推定しうる事を確好た。加硫渦度の時は使用した促進融 がM か DM がたは TS か TT かを区別する事は困離 であるが，乙机は促進機構の本質に関倸するあのであり ロ紙クロマトグラフ法それ自身によるすのでない事を明 らかにした。これをもとにして，末知加硫ゴム試料加ら 促進剂の判別に進みたい。

2）チアゾール系促進剂，チゥラム系促進剂について は，それら加ら变化した生成物の生成機構在既存の理諭 により説明した。.ジフェールメタンをモデルとした実験 結果と本報の結果は著しい一致をみた。

$$
\text { 文献 }
$$

1) 村上，鈒：ゴム協，33，251(1960)

2) 村上，鈒：ゴム協，33，257 (1960)

3) 植田, 古賀. 上田：ゴム協, 29, 164 (1956)

4) 紫田・“ペーパークロマトグラフ法の实際” p. 118 (1957) 共立

5) M. J. Brock and D. L. George: Anal. Chem., 27, 1575 (1955)

6) C. A. Parker: Rubber Chem. Tech., 31, 953 (1958)

7) G.L. Clark, R.L. Le Tourneau, J. M. Ball: Ind. Eng. Chem., 35, 198 (1943)

8) I. Auerbach: Ind. Eng. Chem., 45, 1526 (1953)

9）鈒, 福田：工化, 61, 1377 (1958)

10）福田, 鈒：工化, 62, 1254 (1959)

11）福田, 鈒：炤和 35 年 4 月, 日本化学会13年会請 演会発表，工化投稿巾

12) 銀: 未発表

13) D. Craig, A. E. Juve, W. L. Daviason: Rubber Chem. Tech., 24, 266 (1951)

\section{IDENTIFIGATION OF ACGELERATORS AND ANTIOXYDANTS BY PARTIALLY AGETYLATED PAPER GHROMATOGRAPHY}

\section{IDENTIFICATION OF ORGANIG ACCELERATORS FROM VULCANIZED RUBBER}

S. Murakami, J. Tsurugi (Dept. of Applied Chemistry, University of Osaka Prefecture, Mozu-Umemachi, Sakai, Osaka)

Vulcanization accelerators and their products derived from them during vulcanization reaction were extracted by acetone from pure gum vülcanizates, and were examined by partially acetylated paper chromato- 
graphy.

Zinc salt of 2-mercaptobenzothiazole was identified as a main products, besides 2,2'-dibenzothiazoyl disulfide and 2-mercaptobenzothiazole, when the thiazole type accelerator was used as a compounding ingredient. Amines were also identified from the corresponding sulfenamide type accelerators. Zinc dimethyl dithicarbamate as well as tetramethyl thiuram disulfide and monosulfide were obtained from the thiuram type accelerators. Accelerators such as hexamethylenetetramine, diphenylguanidine, diphenylthiourea were also identified respectively. When commercially mixed accelerators were used, component accelerators or their transformed products were also identified.

Therefore, it was concluded that the partially acetylated paper chromatography is usefull to identify the accelerators from vulcanizates, and is more advantageous than the ordinary paper chromatography. Some information on mechanism for acceleration of the thiazole and thiuram type accelerators were also obtained here.

\section{部分アセチル化ロ紙 クロマトグラフ法による 有機加硫促進剤および老化防止刘の分離・確認}

（第 4 報） 種々な老化防止剂および混合老化防止剤の 部分アセチル化ロ紙クロマトグラフ法

（昭和35年9月29日 牟理）

$\begin{array}{llll}\text { 村 } & \text { 上 } & \text { 伸 } & \text { 絮* } \\ \text { 山 } & \text { 本 } & & \text { 勲: } \\ \text { 銀 } & & \text { 実 } & \text { 夫 }^{*}\end{array}$

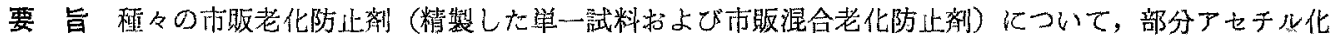
口紙クロマトグラフ法を行い，その Rf 值およびスポットの色から各老化防止剂は十分ての方法により識別

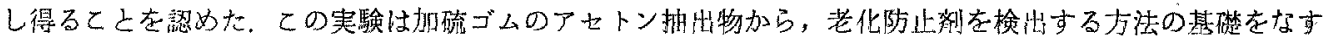
あのである。

\section{1. 緒萻}

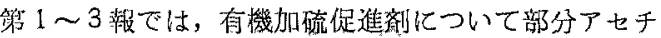
ル化口縕クロマトグシフ法化よる分析を行ったが, 本㫰 では扣硫ゴム中の老化防止剂老分離・確認するための笨 一段階として，精笠した老化防止都がての方法で確認出 来るかどうかを調べた，即ち本攱では，部分アセチル化 口紙クロマトグラフ法により各老化防止剂の Rf 值を求

* 大阪府立大学工学部応用化学科 堺有百售島梅町

※ 現睵は大津ゴム工業株式会社研觉望

+ 現職は日本バルカ一工業株式念社
め，十分それらの確認に役立つととをみとめた，またて の Rf 值をるとにして市販混合老化防止揢の分離・確認 蒿行った。

\section{2. 実験の有法}

\section{1 供試老化防止剂}

表 1 の老化防止剂を定融点迄再結晶して用いた。ただ し老化防止剤 C，224 と混合老化防止剂は市販品を去 まま用いた。

\section{2,2 薬 剂}

口紙のアセチル化に用いた薬剂, 試料の再結晶に用い 